\title{
Performed Substance Administration Planned Change Indicator
}

National Cancer Institute

\section{Source}

National Cancer Institute. Performed Substance Administration Planned Change

Indicator. NCI Thesaurus. Code C93977.

Specifies whether a change in the substance administration in relation to the previous substance administration is planned or not. 